\title{
HABITUS, ANTES QUE MÉTODO, DE UM PESQUISADOR 'POLÍTICO'
}

\author{
Amon Narciso de Barros ${ }^{1}$ \\ Márcio Gomes de Sá2 \\ Pedro Lincoln C. L. de Mattos ${ }^{3}$ \\ Samir Adamoglu de Oliveira ${ }^{4}$
}

\section{APRESENTAÇÃO}

Apesar de toda a diversidade e fragmentação atual das tradições científicas, ainda é possível dizer que está na base dos diversos paradigmas de ciência normal (Kuhn) a ideia de que é ao método que se deve creditar o diferencial e o sucesso desse tipo de conhecimento na sociedade moderna e contemporânea. Em seus albores, a modernidade iluminista imaginou que o método de observação e teste rigorosos, da ciência empírica, seria para nós a chave do universo, até então mítico, religioso e indômito. Graças a essa forma de conhecer, entrávamos em nova era, e os séculos seguintes, inclusive com a revolução industrial europeia, estenderam progressivamente ao conhecimento do homem e de suas sociedades a exigência daquele método. Só muito aos poucos, e já em meados do Século XX, a expressão "método científico" passou a aceitar linguagens e práticas diferenciadas, tentativamente mais adequadas ao "objeto" relações sociais e interioridade humana. De uma forma ou de outra, contudo, as comunidades científicas, agora profissionalizadas,

\footnotetext{
${ }^{1}$ Doutor em Administração pela UFMG. Professor da Fundação Getulio Vargas. E-mail: amon.barros@fgv.br

${ }^{2}$ Doutor em Sociologia pelo Instituto de Ciências Sociais da Universidade do Minho, Portugal. Professor adjunto da Universidade Federal de Pernambuco. E-mail: marciodesa@gmail.com

${ }^{3}$ Professor titular da Universidade Federal de Pernambuco. Doutorado em Government - The London School of Economics and Political Science University of London. Email: plincoln@hotlink.com.br.

${ }^{4}$ Professor Adjunto do Departamento de Administração da Universidade Federal da Paraíba (DADM-UFPB). Professor Colaborador do Programa de Mestrado e Doutorado em Administração da Universidade Positivo (PMDA/UP). Pesquisador Associado do Instituto Brasileiro de Estudos e Pesquisas Sociais (IBEPES). E-Mail: samiroliveira09@hotmail.com
} 
passaram a viver, e ainda vivem, uma hipertrofia do método. A metodologia vai muito além de disciplina propedêutica. $\mathrm{O}$ primado do método, no entanto, pode estar trazendo consigo um efeito perverso sobre a cultura acadêmica: por o foco no processo e, por derivação, o valor no instrumento, em sua operação formal, logo viabilizando uma "industrialização" da vida científica - a metodologia transformada em tecnologia bastante em si.

Assim aparece a primeira motivação deste dossiê, que não deseja, contudo, repisar críticas à corrida produtivista e mesmo à preocupante lacuna, talvez daí originada, de projetos substantivos e socialmente orientados de pesquisa para nossos programas de pós-graduação. Há uma janela por onde se pode olhar fora destas quatro paredes.

A reconhecida obra de Pierre Bourdieu e sua prática científica nos dão oportunidade de reexaminar a questão do método por outro ângulo, agora o sociológico. $\mathrm{Ou}$, melhor, aquele em que se rompem barreiras entre o sociológico e o epistemológico, atribuindo status de legitimidade epistêmica a uma disposição para agir de forma socialmente característica: o habitus. O habitus não é uma categoria lógica, surge de uma relação social, e se mostra sem quaisquer laços de ilação lógica, em um modus operandi da prática da pesquisa. Não se nega o método, mas não é este o conceito condutor da teoria bourdieusiana.

Segundo o próprio Bourdieu, suas elaborações teóricas emergiram de desafios que lhe foram apresentados em situações de pesquisa nas quais sentiu a necessidade de ressignificações conceituais (como a do próprio conceito de habitus). A indissociabilidade entre teoria e metodologia é uma convicção que reaparece por diversas vezes ao longo dos estudos que conduziu, de sua prática do ofício. Muito embora nos Estudos Organizacionais se recorra com frequência aos seus conceitos, para muitos é justamente no seu modo de produção científica onde é possível encontrar seu maior legado (e não na metalinguagem que criou em função dos seus interesses investigativos e estratégicos no campo científico no qual atuava).

O pensamento metodológico de Pierre Bourdieu é o foco teórico deste debate. Ele deixa perguntas no ar, ou desorientados os pesquisadores formados em uma metodologia de fundo epistemológico positivista. A perplexidade não se elimina recorrendo-se aqui à pergunta genérica "o que é o método científico?", que volta, um século, às superadas controvérsias sobre a unidade da ciência e sua neutralidade. Perguntar, no entanto, sobre o lugar do método no habitus científico 
adquire novo sentido, direção em que vai o título quando enuncia: "habitus, antes que método".

É ainda intenção das reflexões que se seguem explorar teoricamente como o conceito bourdieusiano de habitus poderia inspirar, orientar, justificar e por em bons trilhos a prática de um pesquisador que se sente, enquanto tal, participante de uma polis. Esta parece ser uma questão aberta, depois que não prosperaram visões totalitárias da política que conduziam à prioridade do ativismo político na instituição de pesquisa, e também depois que foram mal entendidas ou descontextualizadas estratégias de pesquisa como a "pesquisa-ação" e a "pesquisa participante" em que se pretendia viver um engajamento político. É nosso ofício de pesquisadores - ofício que se faz essencialmente, como tradição, retomando sempre a obra de quem nos precedeu - entender com mais profundidade o sentido sociológico do habitus do pesquisador, que Bourdieu teve o cuidado de associar a casos que estudou, antes de ensaiar apressadas aplicações normativas (quase comportamentais) do habitus a situações mais próximas de nossas vidas. Que a teoria bourdieusiana nos encoraje e nos legitime na busca de uma compreensão política da pesquisa, sim, mas talvez seja preciso primeiro construir tentativamente esta prática. Podem contribuir para isso, no entanto, análises do que sejam as "disposições" que culturalmente predominam em nosso meio e a que estariam vinculadas. 